\title{
PHOSPHORUS-MOLYBDENUM RELATIONSHIP IN SOIL AND RED CLOVER (Trifolium pratense L.) ON AN ACID ANDISOL
}

\author{
Alejandra E. Ribera ${ }^{1}$, María de la Luz Mora ${ }^{1 *}$, Vanessa Ghiselini ${ }^{1}$, Rolando \\ Demanet $^{1}$ and Felipe Gallardo ${ }^{2}$
}

${ }^{1}$ Center of Plant-Soil Interaction and Natural Resources Biotechnology, Scientific and Technological Bioresource Nucleus, Universidad de La Frontera, Avenida Francisco Salazar 01145, Casilla 54-D, Temuco, Chile. ${ }^{2}$ Center of Amelioration and Sustainability of Volcanic Soils, Scientific and Technological Bioresource Nucleus, Universidad de La Frontera, Avenida Francisco Salazar 01145, Casilla 54-D, Temuco, Chile. *Corresponding author: mariluz@ufro.cl

\begin{abstract}
We studied the phosphorous $(\mathrm{P})$ and molybdenum (Mo) relationship in soil and red clover (Trifolium pratense L.) in a non limed and limed acid Andisol of Southern Chile. In soil, we evaluated the effect of different liming $\left(0\right.$ and $\left.2000 \mathrm{mg} \mathrm{kg}^{-1}\right), \mathrm{P}(0,200$ and 400 $\left.\mathrm{mg} \mathrm{kg}{ }^{-1}\right)$, and Mo $\left(0,0.58\right.$ and $\left.0.96 \mathrm{mg} \mathrm{kg}^{-1}\right)$ doses supply on soil available Mo. In addition, the availability of $\mathrm{P}$ and Calcium ( $\mathrm{Ca}$ ) in treated soils was determinated. In red clover, we studied the Mo and P shoot concentrations and dry matter yield in response to the different treatments applied to the soil. Also, we measured the changes produced by Mo uptake in shoot $\mathrm{Cu}$ concentrations. The results showed that both, lime and more strongly $\mathrm{P}$ and Mo additions significantly $(P \leq 0.05)$ increased soil Mo availability. In contrast, soil available $\mathrm{P}$ was not significantly $(P \leq 0.05)$ affected by liming and Mo treatments. A significant high correlation $(\mathrm{r}=0.579$, at $P \leq 0.05)$ was observed among soil Mo availability and shoot Mo concentrations, as well as between soil available $\mathrm{P}$ and shoot concentration of $\mathrm{P}(\mathrm{r}=0.844$, at $P \leq 0.01)$. In this study for all fertilization treatments, shoot $\mathrm{Cu}$ concentrations reached values which are considered as normal for forage species. We also shown that the simultaneous applications of high $\mathrm{P}$ and Mo rates could be produce red clover shoot $\mathrm{Cu} / \mathrm{Mo}$ ratios that should provoke Mo-induced $\mathrm{Cu}$ deficiency (Molybdenosis) for the cattle. Red clover yield was no significantly different in limed and non limed soils. Nevertheless, red clover yield production increased at increasing rates of $\mathrm{P}$ and Mo in both, non limed and limed soil. The major practical implication of these results is that the application of Mo doses equal or superior to $200 \mathrm{~g} \mathrm{ha}^{-1}$ to acid Andisols, are recommendable to obtain appropriate Mo shoot content on red clover. In addition, our results shown that P supply to these soils, rather than liming, is necessary to obtain sufficient values of shoot Mo concentrations in red clover.
\end{abstract}

Keywords: Phosphorous, Molybdenum, Andisol, Red clover.

\section{INTRODUCCION}

Red clover (Trifolium pratense L.) is a forage legume widely used in the Southern Chile due its high yield and good nutritional properties (Ortega et al.,
1998). Nevertheless, in Chilean Andisols in which large areas of red clover pastures are established both, acidic conditions (Mora et al., 2002; 2006) and high anion 
retention capacity (Huang and Violante, 1986) affects the availability of some nutrients, such as phosphorous (P) (Bolan et al. 2003, Barrow et al., 2005; Mora et al., 2006) and molybdenum (Mo) (Haynes, 1983, 1985; López et al., 2007; Vistoso et al., 2005, 2009).

Soil conditions required for adequate yield and quality levels of red clover includes high fertilizer inputs and soil $\mathrm{pH}$ values above 5.5 (Mora et al., 2005; López et al., 2007). Therefore, soil acidity, as well as $\mathrm{P}$ and Mo deficiencies are recognized as limiting factors for red clover production in these soils (Mora et al., 2005). Specifically for Mo, it primer role in legume species is it involvement in the symbiotic process of nitrogen $(\mathrm{N})$ fixation (Marschner, 1995).

According previous studies (Zhang and Sparks, 1989; Vistoso et al., 2009), P strongly compete with Mo by active sites increasing Mo availability in acidic Andisols. In fact, Haynes (1983) and Bolan et al. (2003) indicated that soil Mo availability for plants grown in acid soils depends largely on the extent to which phosphate anions form slowly-soluble complexes or is adsorbed onto mineral surfaces, which are strongly determined by soil pH. Vistoso et al. (2009) reported that in Chilean Andisols phosphate is adsorbed strongly in Fe- and Al- humus complex, whereas molybdate is adsorbed especially in iron oxides. Thus, Mo availability for plant uptake in acidic soils is dependent of soil $\mathrm{pH}$, decreasing its adsorption when soil $\mathrm{Fe}$ and $\mathrm{Al}$ oxides increased (Vistoso et al., 2009). Parfitt (1978) indicated that specific adsorption of phosphate and molybdate by soil colloids decreased as the $\mathrm{pH}$ is increased. Indeed, we earlier results (López et al., 2007), in agreement with those reported by Bolan et al. (2003), have shown that Mo availability is increased in response to lime and $\mathrm{P}$ supply.
On the other hand, we preliminary soil incubation and greenhouse studies (López et al., 2007) showed that soil available Mo increased with Mo fertilization. Moreover, López et al. (2007) found a positive correlation between both, red clover yield and shoot Mo concentrations with soil Mo availability in Chilean Andisols.

Jarrel et al. (1980) reported that Mo toxicity in animal diet is dependent, between other parameters, of cupper $(\mathrm{Cu})$ concentration in the same one. Thus, soil $\mathrm{Cu}$ supply has been shown reduced Mo toxicity. In this way, Molybdenosis is an animal diet disorder defined as Moinduced $\mathrm{Cu}$ deficiency (Suttle, 1991). According to O'Dell (1997), the best indicator of this animal disease is the $\mathrm{Cu} / \mathrm{Mo}$ ratio in animal diet. In the same hand, Whitehead (2000) indicated critical values for $\mathrm{Cu} / \mathrm{Mo}$ ratio in animal foods of 2.0, indicating that lower ratios could be provoke $\mathrm{Cu}$ deficiency for the cattle.

The aim of this study was to evaluate the $\mathrm{P}$ and Mo relationship in an acid Andisol of Southern Chile and its effect on Mo availability and red clover yield and mineral nutrition under greenhouse conditions.

\section{MATERIALS AND METHODS}

\section{Greenhouse experiment}

The experiment was conducted in pots on greenhouse conditions using an Andisol soil (Piedras Negras Series of Southern Chile) never amended with Mo fertilizer. A completely randomized $2 \times 1 \times 3 \times 3$ factorial design was applied.

Soil samples were collected from a natural pasture at top $20 \mathrm{~cm}$. Some of the soil chemical properties are shown in Table 1. The chemical composition of the soil was determined according to the 
Table 1. Some chemical properties of the soil studied.

\begin{tabular}{lc}
\hline Parameters & Soil content \\
\hline $\mathrm{pH} \mathrm{H} \mathrm{H}_{2} \mathrm{O}$ & 5.26 \\
Organic matter $(\%)$ & 18.00 \\
Organic C (\%) & 10.50 \\
Olsen P $\left(\mathrm{mg} \mathrm{kg}^{-1}\right)$ & 2.00 \\
$\mathrm{~K}\left(\mathrm{cmol}_{\mathrm{c}} \mathrm{kg}^{-1}\right)$ & 0.13 \\
$\mathrm{Na}\left(\mathrm{cmol}_{\mathrm{c}} \mathrm{kg}^{-1}\right)$ & 0.05 \\
$\mathrm{Ca}\left(\mathrm{cmol}_{\mathrm{c}} \mathrm{kg}^{-1}\right)$ & 0.73 \\
$\mathrm{Mg}\left(\mathrm{cmol}_{\mathrm{c}} \mathrm{kg}^{-1}\right)$ & 0.30 \\
$\mathrm{Al}\left(\mathrm{cmol}_{\mathrm{c}} \mathrm{kg}^{-1}\right)$ & 0.17 \\
$\mathrm{Al} \mathrm{saturation} \%$ & 12.32 \\
$\mathrm{Al} \mathrm{Ext.}\left(\mathrm{mg} \mathrm{kg}^{-1}\right)$ & 2097 \\
$\mathrm{Cu}\left(\mathrm{mg} \mathrm{kg}^{-1}\right)$ & 0.94 \\
$\mathrm{Mo}(\mu \mathrm{g} \mathrm{kg}$ & 23 \\
\hline
\end{tabular}

methodology described earlier by Sadzawka et al. (2004).

Soil samples $\left(1.1 \mathrm{~kg} \operatorname{pot}^{-1}\right)$ were weighed. Lime $\left(\mathrm{CaCO}_{3}\right)$ was added to half of total pots at final concentrations of $2000 \mathrm{mg} \mathrm{kg}^{-1}$ soil. The lime dose was selected based on previous studies of our research group (Lopez et al., 2007) and applied according to the incubation method described by Mora and Barrow (1996).

Both, non limed and limed samples were fertilized with 0,200 , or $400 \mathrm{mg} P$ $\mathrm{kg}^{-1}$ soil (as $\mathrm{P}_{2} \mathrm{O}_{4}$, Triple Super Phosphate) to render six combinations of acidity and $\mathrm{P}$ content in the soil.

The Mo-pelleted red clover seeds (as ammonium molybdate, $54.31 \%$ of Mo) were sown in each pot. Three doses of Mo were tested $\left(0,0.58\right.$, and $0.96 \mathrm{mg} \mathrm{Mo} \mathrm{kg}{ }^{-1}$ soil, equivalent to 0,200 , and $400 \mathrm{~g} \mathrm{Mo}$ ha $^{-1}$ soil as $\mathrm{Na}_{2} \mathrm{MoO}_{4}$ ).

All treated samples were also fertilized with $40 \mathrm{mg}$ sulphur (S) $\mathrm{kg}^{-1}$ soil (as Sulpomag) and a solution of Boron was applied to each pot at plant emergence state ( 25 post-sown days).

In every experiment, 50 seeds of red clover ( $T$. pratense cv. Toltén) per pot were sown, and after germination plants were thinned to 20 seedlings per pot. Three pots were used as replicates for each treatment, and the pots were periodically repositioned. During the growth period the plants were watered daily with distilled water and one cut was harvested for chemical analysis at $25 \mathrm{~cm}$ plant height.

\section{Soil chemical analysis}

The soil chemical analyzed according Sadzawka et al. (2004). P was extracted by the Olsen bicarbonate method and analyzed by the Murphy and Riley method as described previously (1962). $\mathrm{Ca}$ was extracted with a diethylene triaminepentaacetic acid (DTPA)- $\mathrm{CaCl}_{2}$ tiethanolamine (TEA) solution ( $\mathrm{pH} 7.3)$ and analyzed by Flame Atomic Absorption Spectrophotometry (FAAS).

The available Mo was determined by extracting $10 \mathrm{~g}$ of soil with a solution of $20 \mathrm{ml}$ of ammonium bicarbonate (AB)DTPA (Soltanpour et al., 1982). The suspension was shaken for $15 \mathrm{~min}$, filtered, and the available Mo was determined by Graphite-Furnace (GF 90) Atomic Adsorption Spectrophotometer, UNICAM 960. Soil pH was measured by potentiometry in a 1:2.5 (w/v) soil/distilled water suspension. All determinations were carried out at the end of the assay, after the red clover harvest.

\section{Plant chemical analysis}

Shoots was weighed and the samples was dried at $65^{\circ} \mathrm{C}$ for $48 \mathrm{~h}$ to determine both dry matter (DM) and foliar mineral concentrations. For P shoot concentration the molybdo-vanadate method as described by Sadzawka et al. (2007) was 
used. The calcium (Ca) and $\mathrm{Cu}$ shoot concentrations were determined by Atomic Absorption Spectrophotometry (AAS), after that dry plant samples were ashed at $500^{\circ} \mathrm{C}$ for $4-8 \mathrm{~h}$ and digested with a acid mixture composed by $\mathrm{HNO}_{3}$ $\mathrm{HCl}$ and $\mathrm{H}_{2} \mathrm{O}$ (Sadzawka et al. 2007). The Mo chemical analysis was carried out using AAS coupled to a Graphite-Furnace (AAS-GF), after that dry shoot samples were ashed at $500^{\circ} \mathrm{C}$ for $4-8 \mathrm{~h}$, dissolved in diluted $\mathrm{HCl}$, and filtered (Karla, 1998).

\section{Statistical analysis}

Data were assessed by two-way ANOVA using SigmaStat 3.1 software. Means were compared using Tukey's test $(P \leq$ 0.05). The effect of fertilization treatments in non limed and limed soil was analyzed separately. Pearson $r$ correlation $(P \leq 0.01$ and $P \leq 0.05)$ was calculated and used to test the relationships between two response variables (JMP version 5.0.1 statistical program, SAS Institute).

\section{RESULTS AND DISCUSSION}

\section{Soil nutrients availability}

The results of $\mathrm{pH}$ values and the soil $\mathrm{Ca}$, $\mathrm{P}$, and Mo availability in non limed and limed soil at different $\mathrm{P}$ and Mo doses are showed in Table 2. In agreement with previous works (Haynes, 1985; Bolan et al. 2003; Lopez et al. 2007), the results indicated that soil available Mo increased slightly in response to liming but strongly with Mo and $\mathrm{P}$ doses supplied. According to Bolan et al. (2003) and Goldberg et al. (2002), lime application substantially increased the availability of native Mo in soils. Mora and Barrow (1996) agree that lime increases the soil $\mathrm{pH}$, then the negative charge of soil components also increase, which can promote anion desorption. In fact, Goldberg et al. (1996) observed that the maximum Mo adsorption on amorphous iron $(\mathrm{Fe})$ and aluminum (Al) oxides minerals occur at soil $\mathrm{pH}$ from 4.0 to 5.0 , decreasing at increasing $\mathrm{pH}$. Besides, Vistoso et al. (2009) shown that in Chilean Andisols the adsorption of molybdate and phosphate decreased as $\mathrm{pH}$ values are increased, detecting adsorption levels of $100 \%$ for both anions at $\mathrm{pH} 4.0$. The results of the same work also indicated that with $\mathrm{pH}$ increases of 5.0 to 6.0 , the adsorption of Mo diminished from $78 \%$ to $66 \%$. These effects may be particularly important in south Chilean Andisols, in which liming is frequently accompanied by high $\mathrm{P}$ additions (Mora et al., 1999; 2002). Barrow et al. (2005) report that both, $\mathrm{P}$ and Mo adsorption are described by ligand exchange mechanism and then an increase in hydroxyl ions could be made both anions more available. Many sites with high affinity for molybdate in soils may be blocked by phosphate anions (Goldberg et al. 2002). Phosphate anion competes strongly with molybdate for active site in Chilean Andisols (Vistoso et al., 2005) and this capacity decreased at increasing $\mathrm{pH}$ (Barrow, 1986; Xie and MacKenzie, 1991; Vistoso et al., 2009).

In this study, soil $\mathrm{pH}$ values increased by the effect of lime application from averages of 5.33 to 5.56. Furthermore, we observed a significant high correlation ( $\mathrm{r}=0.930$, at $P \leq 0.01$ ) between soil $\mathrm{Ca}$ availability and soil $\mathrm{pH}$ values (Figure 1). It is noteworthy that in acid soils available $\mathrm{Ca}$ is very low. When soil $\mathrm{pH}$ increase by liming, then an increment of negative charges is provoked and the cationic interchange capacity of soils is increased. This allows to infer that a large amount of $\mathrm{Ca}$ applied is retained by new interchange sites (Galindo and Escudey, 1985).

Our results showed that the higher value of available Mo in non limed soil (2150 $\mu \mathrm{g} \mathrm{kg}^{-1}$ soil) was obtained with the highest $\mathrm{P}$ and Mo rates. However, in 
Table 2. Effect of $\mathrm{P}$ and $\mathrm{Mo}$ additions on soil $\mathrm{pH}$ and $\mathrm{Ca}, \mathrm{P}$, and $\mathrm{Mo}$ availability in non limed and limed soil at the end of greenhouse experiment.

\begin{tabular}{|c|c|c|c|c|c|}
\hline \multicolumn{2}{|c|}{ Fertilization doses } & \multirow[b]{2}{*}{$\begin{array}{l}\text { Soil } \\
\text { pH }\end{array}$} & \multicolumn{3}{|c|}{ Soil available nutrients } \\
\hline $\begin{array}{c}P \\
\left(\mathrm{mg} \mathrm{kg}^{-1}\right)\end{array}$ & $\begin{array}{c}\text { Mo } \\
\left(\mathrm{g} \mathrm{ha}^{-1}\right)\end{array}$ & & $\begin{array}{c}\text { Ca } \\
\left(\mathrm{cmol}_{\mathrm{c}} \mathrm{kg}^{-1}\right)\end{array}$ & $\begin{array}{c}P \\
\left(\mathrm{mg} \mathrm{kg}^{-1}\right)\end{array}$ & $\begin{array}{c}\text { Mo } \\
\left(\mu \mathrm{kg}^{-1}\right)\end{array}$ \\
\hline & & & Non & soil & \\
\hline \multirow[t]{3}{*}{$\mathbf{0}$} & $\mathbf{0}$ & 5.26 & $3.09 \mathbf{b}$ & $9.00 \mathrm{c}$ & $22 \mathbf{e}$ \\
\hline & 200 & 5.29 & $3.08 \mathbf{b}$ & $9.00 \mathrm{c}$ & $551 \mathbf{d}$ \\
\hline & 400 & 5.31 & $3.11 \mathrm{~b}$ & $9.67 \mathrm{c}$ & $1335 \mathrm{c}$ \\
\hline \multirow[t]{3}{*}{200} & $\mathbf{0}$ & 5.33 & $3.53 \mathbf{a b}$ & $21.67 \mathbf{b}$ & $24 \mathbf{e}$ \\
\hline & 200 & 5.37 & $3.45 \mathbf{a b}$ & $20.00 \mathbf{b}$ & $797 \mathbf{d}$ \\
\hline & 400 & 5.39 & $3.52 \mathbf{a b}$ & $20.33 \mathbf{b}$ & $1719 \mathbf{b}$ \\
\hline \multirow[t]{4}{*}{400} & $\mathbf{0}$ & 5.36 & $3.67 \mathbf{a}$ & $29.00 \mathbf{a}$ & $28 \mathbf{e}$ \\
\hline & 200 & 5.36 & $3.79 \mathbf{a}$ & $33.33 \mathbf{a}$ & $817 \mathbf{d}$ \\
\hline & 400 & 5.33 & $3.84 \mathbf{a}$ & $33.67 \mathbf{a}$ & $2150 \mathbf{a}$ \\
\hline & & \multicolumn{4}{|c|}{ Limed soil } \\
\hline \multirow[t]{3}{*}{$\mathbf{0}$} & $\mathbf{0}$ & 5.61 & $6.58 \mathbf{b}$ & $8.67 \mathrm{c}$ & $27 \mathbf{f}$ \\
\hline & 200 & 5.59 & $6.47 \mathbf{b}$ & $8.67 \mathrm{c}$ & $285 \mathbf{e}$ \\
\hline & 400 & 5.61 & $6.49 \mathbf{b}$ & $8.67 \mathrm{c}$ & 892 c \\
\hline \multirow[t]{3}{*}{200} & $\mathbf{0}$ & 5.57 & $6.75 \mathbf{a b}$ & $20.00 \mathbf{b}$ & $31 \mathbf{f}$ \\
\hline & 200 & 5.52 & $7.01 \mathbf{a b}$ & $22.67 \mathbf{b}$ & $678 \mathrm{~d}$ \\
\hline & 400 & 5.52 & $6.84 \mathbf{a b}$ & $23.00 \mathbf{b}$ & $1971 \mathbf{a}$ \\
\hline \multirow[t]{3}{*}{400} & 0 & 5.52 & $7.10 \mathbf{a}$ & $31.00 \mathrm{a}$ & $32 \mathbf{f}$ \\
\hline & 200 & 5.54 & $7.12 \mathbf{a}$ & $31.00 \mathrm{a}$ & 985 c \\
\hline & 400 & 5.57 & $7.10 \mathbf{a}$ & $31.33 \mathbf{a}$ & 1475 b \\
\hline
\end{tabular}

Means with different letters show significant differences between treatments according to the Tukey test $(P \leq 0.05)$. The effect of fertilization treatments in non limed and limed soil was analyzed separately.

limed soil supplied with $200 \mathrm{mg} \mathrm{kg} \mathrm{kg}^{-1}$ of $\mathrm{P}$ and $400 \mathrm{~g} \mathrm{Mo} \mathrm{ha}^{-1}$, available Mo (1971 $\left.\mu \mathrm{g} \mathrm{kg}^{-1}\right)$ was higher than those detected with the same Mo doses and $400 \mathrm{mg} \mathrm{kg}^{-1}$ of $\mathrm{P}\left(1475 \mu \mathrm{g} \mathrm{kg}^{-1}\right)$.

As expected, we found that soil available $\mathrm{P}$ increased at increasing $\mathrm{P}$ rates applied in both, limed and non limed soil. Thus, soil available $P$ ranged from 8 - 9 $\mathrm{mg} \mathrm{kg}^{-1}$ (control plants) to $20-33 \mathrm{mg} \mathrm{kg}^{-1}$ when $\mathrm{P}$ was applied. The levels of available $\mathrm{P}$ were similar in non limed and limed soil, irrespective to Mo doses applied (Table 2).

Regarding liming effects on soil available $\mathrm{P}$ in Andisols, conflicting views are held. Indeed, lime has been reported to increase or decrease $\mathrm{P}$ adsorption in different soils (Haynes, 1985) and even within the same soil type (Haynes, 1983). 


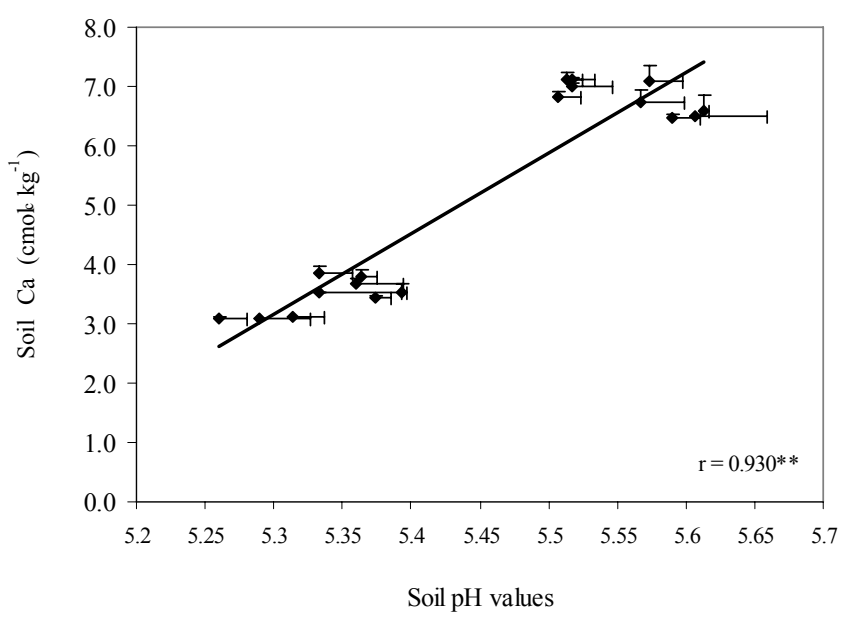

Figure 1. Correlation (Pearson's) level among soil available $\mathrm{Ca}$ and different $\mathrm{pH}$ values in the soil studied. The Pearson correlation was used to test the relationships between the response variables. Asterisks denote significance $(* P \leq 0.05, * * P \leq 0.01)$. Available $\mathrm{Ca}$ and soil $\mathrm{pH}$ values of non limed and limed soil were included for the analysis.

Mora et al. (1999) demonstrated that lime addition on acid south Chilean Andisols reduces $\mathrm{P}$ adsorption capacity. They also shown that lime supply on soils with $\mathrm{P}$ high initial levels diminishes soil available P. While, when lime was apply on soils with low available $P$, the amendment cause an increase of soil $\mathrm{P}$ availability.

According to Naidu et al. (1990), when soil $\mathrm{pH}$ increase until values over 6.0 in response to liming, then soil available $\mathrm{P}$ should be decrease as a result of insoluble Ca-P complex formation. Besides, lime supply increases $\mathrm{Ca}$ concentration on charged soil surfaces turn the potential of the adsorption plane less negative, increasing $\mathrm{P}$ adsorption capacity (Barrow, 1980). However, in this study we suggest that the effect of both, red clover rhizosphere and $\mathrm{P}$ uptake simultaneous mechanisms, did not allow to detect differences for soil available $\mathrm{P}$ between limed and non limed soils.

Previously, López et al. (2007) found that Mo additions of $0.58 \mathrm{mg} \mathrm{kg}$ soil (equivalent to $200 \mathrm{~g} \mathrm{Mo} \mathrm{ha}^{-1}$ ) to limed and
P fertilized (200 mg P kg ${ }^{-1}$ ) acid Andisols significantly increased available Mo up to $200 \mu \mathrm{g} \mathrm{kg}^{-1}$ soil. These results are in agreement with the data obtained in the present study. Whitehead (2000) indicated that normal values of Mo content in soils ranged from 100 to $4000 \mu \mathrm{g} \mathrm{kg}^{-1}$ soil.

\section{Shoot mineral concentration and dry matter production of red clover}

The effect of fertilizer treatments on Mo and $\mathrm{P}$ red clover shoot concentrations are shown in Figure 2. In agreement with previous results (Vistoso, 2005; Lopez et al., 2007), we found that Mo uptake increased in response to liming and $\mathrm{P}$ supply (Figure 2).

It is known that lime additions to acid soils increases the root growth of legume forages, permitting a greater nutrient uptake by plants (Brauer et al. 2002). In addition, as we indicated above, our data showed that Mo availability in limed and $P$ fertilized soils was higher than available Mo in untreated soils. These antecedents can be explain the high values of shoot 

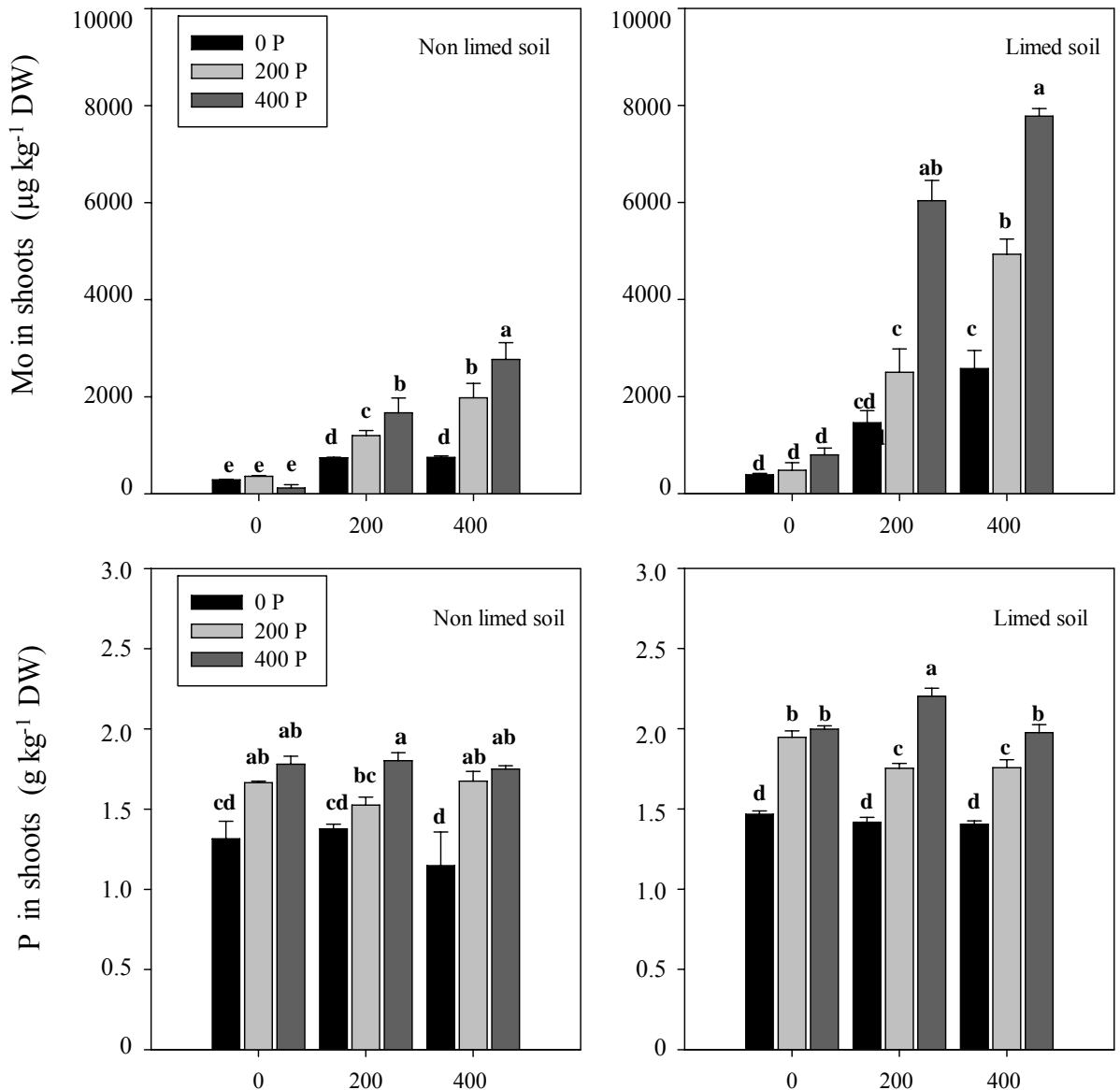

Molybdenum treatments $\left(\mathrm{g} \mathrm{ha}^{-1}\right)$

Figure 2. Shoot $\mathrm{P}$ and Mo concentrations on red clover grown in non limed and limed soil at different $\mathrm{P}$ and Mo additions. Means with different letters show significant different between treatments according to the Tukey test $(P \leq 0.05)$. The effect of fertilization treatments in non limed and limed soil was analyzed separately.

Mo detected here in plants grown in soil supplied with lime and $P$.

Moreover, we found that shoot Mo concentrations in red clover increased as the level of Mo rates applied was increased both, in non limed and limed soil. Similar results have been reported previously by Adams (1997), Vistoso (2005) and Lopez et al. (2007). In fact, our results indicated that Mo concentration in shoots was significantly correlated $(\mathrm{r}=0.579 ; P \leq 0.05)$ with Mo availability in the soil (Figure 3a).

Shoot Mo concentration in red clover plants untreated with Mo and $\mathrm{P}$ was 0.29 $\mathrm{mg} \mathrm{kg}{ }^{-1} \mathrm{DM}$ in non limed soil and 0.39 $\mathrm{mg} \mathrm{kg}{ }^{-1} \mathrm{DM}$ in limed soil. Then, the addition of Mo doses equivalent to $400 \mathrm{~g}$ 
$\mathrm{ha}^{-1}$ plus $200 \mathrm{mg} \mathrm{kg}^{-1}$ of $\mathrm{P}$ to non limed soil increased Mo shoot concentrations to $1980 \mu \mathrm{g} \mathrm{Mo} \mathrm{kg}^{-1} \mathrm{DM}$, and to $2770 \mu \mathrm{g}$ Mo $\mathrm{kg}^{-1} \mathrm{DM}$ when $400 \mathrm{mg} \mathrm{kg}^{-1}$ of $\mathrm{P}$ were applied. Furthermore, in limed soil the effect of $\mathrm{P}$ doses on shoot Mo concentration was higher than those detected in non limed soil. With P supply of 200 and $400 \mathrm{mg} \mathrm{P} \mathrm{kg}^{-1}$ in limed soil, shoot Mo concentrations increased until to 4930 and $7780 \mu \mathrm{g} \mathrm{kg}^{-1}$, respectively. Bennet (1993), reported critical, sufficient, and toxic levels indexes of Mo in plant shoots ranges from 0 to $100 \mu \mathrm{g}$ $\mathrm{kg}^{-1} \mathrm{DM}$, from 100 to $500 \mu \mathrm{g} \mathrm{kg}^{-1} \mathrm{DM}$, and from 10000 to $50000 \mu \mathrm{g} \mathrm{kg}^{-1} \mathrm{DM}$. However, Lopez et al. (2007) determined that the critical Mo concentration deficiency value for red clover grown in the soil studied here was $500 \mu \mathrm{g} \mathrm{kg}^{-1}$ of DM. Accordingly, Shuman (1994) reports that the critical concentration of Mo for red clover plants ranged between 20 to $490 \mu \mathrm{g} \mathrm{kg}^{-1} \mathrm{DM}$, while values from 500 to $1000 \mu \mathrm{g} \mathrm{kg} \mathrm{kg}^{-1} \mathrm{DM}$ are defined as appropriate levels.

It is important mentioned that normal levels of Mo concentration for animal diet are values lower than $5000 \mu \mathrm{g} \mathrm{kg}^{-1} \mathrm{DW}$. In USA, Canada, New Zealand, and Switzerland, toxic effects of Mo foliar concentration have been found on forage species containing between 15 to $300 \mathrm{mg}$ Mo kg-1 DM (Adriano, 2001).

Taking these antecedents as a basis, we suggest that the simultaneous application of Mo supply and high doses of $\mathrm{P}$ to limed south Chilean Andisols can be provoke toxic levels of Mo content on red clover for the cattle. Therefore, irrespective of lime and $\mathrm{P}$ supplies, we demonstrated that soil Mo additions of $200 \mathrm{~g} \mathrm{ha}^{-1}$ should be sufficient to reach normal levels of Mo in plants (up to 500 $\mu \mathrm{g} \mathrm{kg}^{-1}$ of DW).

On the other hand, our results indicated that shoot $\mathrm{P}$ concentrations of red clover plants grown in limed soil increased respect to those grown in non limed soils (Figure 2). These results are in agree with previous reports (Vistoso, 2005; Mora et al., 2002). Also and as expected, we found that the application of increasing $P$ rates increased steadily shoot $\mathrm{P}$ concentration according to Jones et al. (1980) and Basak et al. (1982). Shoot P concentrations were positively correlated ( $\mathrm{r}=0.844, P \leq 0.01)$ with soil available $\mathrm{P}$ levels (Figure 3b). In addition, we demonstrated that Mo supply do not affected significantly P uptake (Figure 2).

In this study, $\mathrm{P}$ concentration in shoots ranged from 1.15 to $2.20 \mathrm{~g} \mathrm{~kg}^{-1} \mathrm{DM}$. The highest value of shoot $\mathrm{P}\left(2.20 \mathrm{~g} \mathrm{~kg}^{-1} \mathrm{DM}\right)$ was observed in plants grown in limed soil treated with $400 \mathrm{mg} \mathrm{P} \mathrm{kg}{ }^{-1}$ and $200 \mathrm{~g}$ $\mathrm{Mo} \mathrm{ha}^{-1}$. In this hand, Jones et al. (1980) reported normal values of shoot concentration of $\mathrm{P}$ between 2.0 to $2.8 \mathrm{~g}$ $\mathrm{kg}^{-1} \mathrm{DM}$, whereas Bolland et al. (1995) indicated normal levels ranged from 2.0 to $3.0 \mathrm{~g} \mathrm{~kg}^{-1} \mathrm{DM}$. These $\mathrm{P}$ concentrations values are similar to those reported as normal $\mathrm{P}$ shoot contents in others legumes forage, such as subterraneum clover (Trifolium subterraneum L.) with $2.25 \mathrm{~g}$ $\mathrm{kg}^{-1}$ DW (Drlica and Jackson, 1979) and white clover (Trifolium repens L.) with $3.50 \mathrm{~g} \mathrm{~kg}^{-1} \mathrm{DM}$ (Sinclair et al., 1997).

In the present study, we found that shoot $\mathrm{Cu}$ concentrations of red clover in response to fertilization treatments was negatively correlated with Mo availability in the soil $(\mathrm{r}=0.631$, at $P \leq 0.01)$ (Figure 4). Indeed, the highest shoot $\mathrm{Cu}$ levels were observed in control plants grown in non limed soil (12.47 mg Cu kg-1 DM, data not shown). These values were decreasing at increasing Mo as well as when $\mathrm{P}$ doses was increased, reaching $6.99 \mathrm{mg} \mathrm{Cu} \mathrm{kg}{ }^{-1} \mathrm{DM}$ for plants grown under the treatment of $400 \mathrm{~g} \mathrm{Mo} \mathrm{ha}^{-1}$ plus $\mathrm{P}$ supplies of $400 \mathrm{mg} \mathrm{kg}$ (data not shown). In limed soil, a similar tendency was observed. Nevertheless, in our study shoot $\mathrm{Cu}$ concentrations ranged inside 

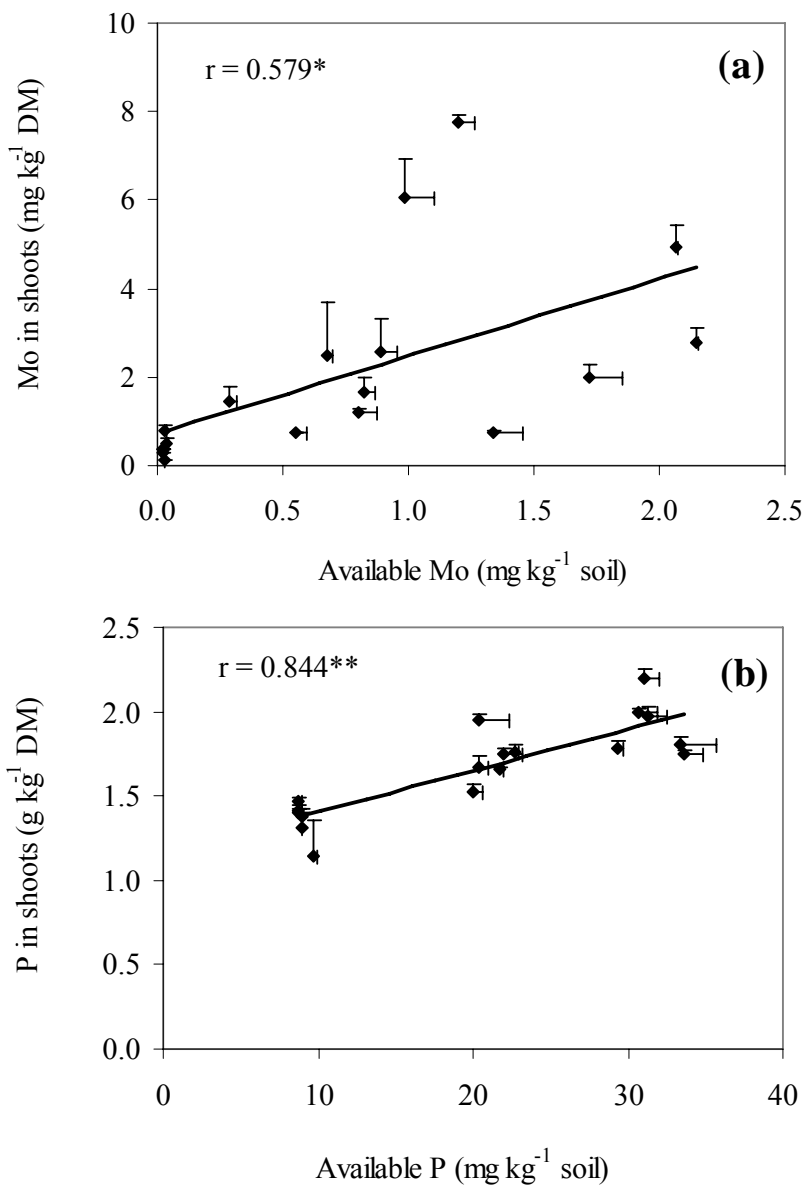

Figure 3. Correlation levels among soil $\mathrm{P}$ availability and shoot $\mathrm{P}$ concentrations (a) and among soil available Mo and shoot Mo concentrations (b) in red clover plants grown in the soil studied. The Pearson correlation was used to test the relationships between the response variables. Asterisks denote significance $\left({ }^{*} P \leq 0.05,{ }^{*} P \leq 0.01\right)$. Both, data obtained for non limed and limed soil were included for the analysis.

normal values for forage species according Mitchell et al. (1957) and Kabata-Pendias and Pendias (2000). Moreover, we detected shoot $\mathrm{Cu} / \mathrm{Mo}$ ratios from 1.07 to 58.49 (Table 3 ). Whitehead (2000) reports critical $\mathrm{Cu} / \mathrm{Mo}$ ratios in animal foods of 2.0, indicating that lower ratios could be provoke $\mathrm{Cu}$ deficiency (Molybdenosis) for the cattle.
According to these reports, we also demonstrated that the addition of $\mathrm{P}$ and Mo high fertilizers rates to acid Southern Chilean Andisols could be produce red clover shoot $\mathrm{Cu} / \mathrm{Mo}$ ratios that should be induce $\mathrm{Cu}$ deficiency. This aspect is especially important in limed soil, in which soil available $\mathrm{P}$ and Mo are higher than in non limed soil. 


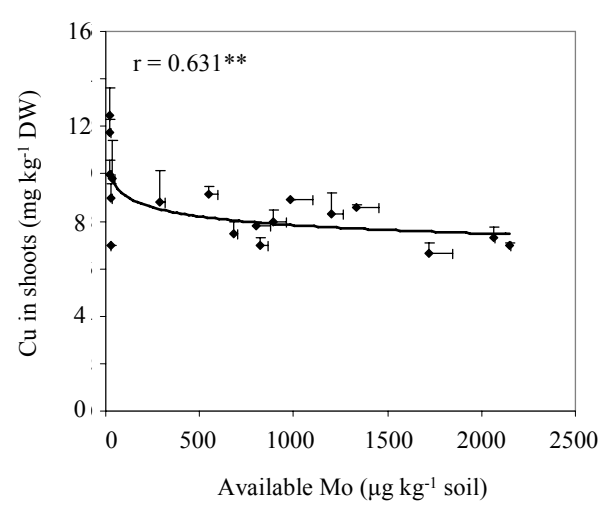

Figure 4. Correlation level among soil available $\mathrm{Mo}$ and shoot $\mathrm{Cu}$ concentration of red clover grown in the soil studied. Significant at $* * 0.01$ probability level. Data obtained for non limed and limed soil were included for the analysis.

Table 3. $\mathrm{Cu} / \mathrm{Mo}$ ratios on red clover shoots treated with different $\mathrm{P}$ and Mo addition in non limed and limed soil.

\begin{tabular}{cccc}
\hline \multicolumn{2}{c}{ Fertilization Doses } & \multicolumn{2}{c}{ Shoot Cu/Mo ratios } \\
$\mathbf{P}\left(\mathbf{m g ~ k g}^{-1}\right)$ & $\mathbf{M o}\left(\mathbf{g ~ h a}^{-1}\right)$ & Non limed soil & Limed soil \\
\hline 0 & 0 & 43.32 & 25.74 \\
& 200 & 12.32 & 6.65 \\
& 400 & 11.48 & 3.94 \\
200 & 0 & 32.79 & 24.18 \\
& 200 & 6.60 & 4.20 \\
400 & 400 & 3.53 & 1.53 \\
& 0 & 58.49 & 11.77 \\
& 200 & 4.45 & 1.53 \\
& 400 & 2.61 & 1.07 \\
\hline
\end{tabular}

We shown that red clover DM production in limed soil was similar or higher than those observed for plants grown in non limed soils (Table 4). Demanet et al. (1999) reported that red clover is a forage specie tolerant to soil acidity conditions, specially adapted to acid soils of Southern Chile. On the other hand and in agreement with Holford (1985) and Vistoso (2005), we found that shoot DM production was increased at $\mathrm{P}$ increasing rates in both, limed and non limed soil. These increases reached until $25 \%$ in limed soil with the highest $\mathrm{P}$ doses. Respect to the effect of Mo supply on red clover yield, in non limed soil DM production was increased when soil Mo rates was increased. These increments were higher in the presence of $P$ treatments (until 17\%). Similarly, in limed soil, the red clover yield was increased with Mo addition, except for the treatment with the simultaneous application of the highest $\mathrm{P}$ and Mo doses, also reaching increases of about $17 \%$ respect to the control.

López et al. (2007) demonstrated that red clover DM production was increased at increasing doses of Mo applied to four South Chilean Andisols. According the results of the same work, yield was stabilized when $0.46 \mathrm{mg}$ Mo $\mathrm{kg}^{-1}$ (equivalent to $160 \mathrm{~g} \mathrm{Mo} \mathrm{ha} \mathrm{g}^{-1}$ ) were applied. Wheeler (1998), observed that the production of white clover in the first year increased in response to the application of $150 \mathrm{~g}^{\mathrm{Mo} \mathrm{ha}}{ }^{-1}$. Moreover, Vistoso (2005) reported that the highest DM production level of white clover was obtained in limed South Chilean Andisols with $\mathrm{P}$ rates of 100 to $200 \mathrm{mg} \mathrm{P} \mathrm{kg}^{-1}$ soil and Mo doses of 4 to $6 \mathrm{mg} \mathrm{Mo} \mathrm{kg}^{-1}$ soil.

We also found that in non limed soil the highest red clover production was detected for plants treated with the highest $\mathrm{P}$ and Mo doses $\left(6.70 \mathrm{~g} \mathrm{pot}^{-1}\right)$, increased $28 \%$ higher compared with control plants $\left(4.80 \mathrm{~g} \mathrm{pot}^{-1}\right)$. While, the maximum production in limed soil was obtained with $400 \mathrm{mg} \mathrm{P} \mathrm{kg}^{-1}$ soil and $200 \mathrm{~g} \mathrm{Mo} \mathrm{ha}^{-1}$ soil $\left(6.87 \mathrm{~g} \mathrm{pot}^{-1}\right)$, being this value $30 \%$ higher than the DM production of control plants (Table 4).

According to our results, lime supplies to the soil studied not affected importantly red clover DM production of red clover, provided that heavy $\mathrm{P}$ doses are applied. Demanet et al., (1999) indicated that red clover can resist high soil acidity showing high DM yields. 
Table 4. Shoot dry matter (DM) production of Red clover at different $\mathrm{P}$ and Mo additions in non limed and limed soil.

\begin{tabular}{cccc}
\hline \multicolumn{2}{c}{ Fertilization Doses } & \multicolumn{2}{c}{ Dry Matter $\left(\mathbf{g ~ p o t}^{-\mathbf{1}}\right)$} \\
$\mathbf{P}\left(\mathbf{m g ~ k g}^{-\mathbf{1}}\right)$ & $\mathbf{M o}\left(\mathbf{g ~ h a}^{-\mathbf{1}}\right)$ & Non limed soil & Limed soil \\
\hline $\mathbf{0}$ & $\mathbf{0}$ & $4.80 \mathbf{e}$ & $5.16 \mathbf{~ d}$ \\
& $\mathbf{2 0 0}$ & $4.78 \mathbf{e}$ & $5.52 \mathbf{c d}$ \\
& $\mathbf{4 0 0}$ & $4.97 \mathbf{~ d e}$ & $5.69 \mathbf{c d}$ \\
$\mathbf{2 0 0}$ & $\mathbf{0}$ & $5.46 \mathbf{c d}$ & $5.12 \mathbf{d}$ \\
& $\mathbf{2 0 0}$ & $6.20 \mathbf{~ b}$ & $6.04 \mathbf{~ b c}$ \\
& $\mathbf{4 0 0}$ & $6.32 \mathbf{~ b}$ & $5.97 \mathbf{~ b c}$ \\
$\mathbf{4 0 0}$ & $\mathbf{0}$ & $5.75 \mathbf{~ b c}$ & $6.47 \mathbf{~ a b}$ \\
& $\mathbf{2 0 0}$ & $6.18 \mathbf{~ b}$ & $6.87 \mathbf{~ a}$ \\
& $\mathbf{4 0 0}$ & $6.70 \mathbf{~ a}$ & $6.42 \mathbf{~ a b}$ \\
\hline
\end{tabular}

Means with different letters show significant differences between treatments according to the Tukey test $(P \leq 0.05)$. The effect of fertilization treatments on dry matter production in non limed and limed soil was analyzed separately.

According to the same study, this forage legume is adapted to south Chilean acid soils, requiring only a few amounts of lime for its successful growth. They agree that lime supply of 1 ton $\mathrm{ha}^{-1}$ (with $\mathrm{P}_{2} \mathrm{O}_{4}$ rates of $180 \mathrm{~kg} \mathrm{ha}^{-1}$ ) are sufficient to reach the maximum yield of red clover pastures. Moreover, they also had shown that the yield responses of red clover to lime additions are detectable only at last productive season.

\section{CONCLUSIONS}

The results presented in this paper shown that lime and $\mathrm{P}$ applications to south acid Chilean Andisols significantly increased soil available Mo and shoot Mo concentration in red clover plants. Nevertheless, we found that liming and Mo supply did not affected soil P availability. In addition, our results confirm previous reports indicating that $\mathrm{P}$ heavy doses supply are necessary to reach sufficient levels of shoot $\mathrm{P}$ concentration of red clover grown in acid Andisols and that $\mathrm{P}$ fertilization is more important for red clover yield than liming in these soils.

Furthermore, we had shown that the additions of Mo doses equivalent to $200 \mathrm{~g}$ $\mathrm{ha}^{-1}$ and $200 \mathrm{mg} \quad \mathrm{P} \quad \mathrm{kg}^{-1}$ soil are recommendable to obtain appropriate $\mathrm{Mo}$ shoot content in pastures of red clover grown in limed Andisols.

Also, under this fertilization strategy proposed, shoot $\mathrm{Cu}$ foliar concentrations ranged values which are considered normal levels for forage legume species. We also found that the applications of high $\mathrm{P}$ and Mo supply simultaneously, could be produce red clover shoot $\mathrm{Cu} / \mathrm{Mo}$ ratios that should be cause $\mathrm{Cu}$ deficiency for the cattle. 


\section{ACKNOWLEDGEMENTS}

This work was supported by the International Cooperation FONDECYT project 7060093 and by the FONDECYT project 1061262 and Grants.

\section{REFERENCES}

Adams, J.F. 1997. Yield response to molybdenum by field and horticultural crops. In: Gupta, U.C. (Ed). Molybdenum in agriculture. Cambridge University Press, Cambridge, U.K., p. 182-201.

Adriano, D.C. 2001. Trace elements in terrestrial environments. Springer-Verlag, New York, N.Y., $867 \mathrm{p}$

Barrow, J., Bowden, J., Posner, A., Quirk, J., 1980. Describing the effects of electrolyte on adsorption of phosphate by a variable charge surface. Australian Journal of Soil Research 18 , 395-404.

Barrow, N.J. 1986. Testing a mechanistic model, II. The effects of time and temperature on the reaction of zinc with a soil. European Journal of Soil Science 37 (2), 277-286.

Barrow, N.J., Cartes, P. and Mora, M.L. 2005. Modifications to the Freundlich equation to describe anion sorption over a large range and to describe competition between pairs of ions. European Journal of Soil Science 56, 601-606.

Basak, A., Mandal, N., Haldar, M. 1982. Interaction of phosphorus and molybdenum in relation to uptake and utilization of molybdenum, phosphorus, zinc, copper and manganese by rice. Plant and Soil 68, 261-269.

Bennet, W. 1993. Plant nutrient utilization and diagnostic plant symptoms. In: Bennet, W.F. Nutrient deficiencies and toxicities in crop plants. American Phytopathological Society Press, St Paul, M.N., pp. 1-7.

Bolan, N., Adriano, D., Curtin, D. 2003. Soil acidification and liming interactions with nutrient and heavy metal transformation and bioavailability. Advances in Agronomy 1, 215272.
Bolland, M.D.A., Clarke, M.F., Yeates, J.S. 1995. Critical phosphorus concentration for subterranean clover in the high rainfall areas of south-western Australia. Communication in Soil Science and Plant Analysis 26, 1427-1440.

Brauer, D., Ritchey, D., Belesky, D. 2002. Effects of lime and calcium on root development and nodulation of clovers. Crop Science 42, 1640-1646.

Demanet, R., Schnettler, B., Mora, M.L. 1999. Efecto del encalado y su relación con los nutrientes sobre la producción de pasturas en suelos ácidos. Frontera Agrícola 5 (1 y 2), 95110 .

Drlica, D.M., Jackson, T.L. 1979. Effects of stage of maturity on $\mathrm{P}$ and $\mathrm{S}$ critical levels in subterranean clover. Agronomy Journal 71, 824828.

Galindo, G., Escudey, M. 1985. Interacciones superficie-solución en suelos volcánicos y sus componentes. In: Tosso, J. (Ed.). Suelos Volcánicos de Chile, Instituto de Investigaciones Agropecuarias, Ministerio de Agricultura, Santiago, Chile, pp. 305-329.

Goldberg, S., Forster, H.S., Godfrey, C.L. 1996. Molybdenum adsorption on oxides, clay minerals, and soils. Soil Science Society of America Journal 60, 425-432.

Goldberg, S., Lesch, S., Suarez, D. 2002. Predicting molybdenum adsorption by soils using soil chemical parameters in the constant capacitance model. Soil Science Society of America Journal 66, 1836-1842.

Haynes, R.J. 1983. Effect of lime and phosphate applications on the absorption of phosphate, sulphate, and molybdate by a Spodosol. Soil Science 135, 221-227.

Haynes, R.J. 1985. Effect of liming on the adsorption of inorganic phosphate by soils. In: Jackson, B.L.J., Edmeades, D.C. (Eds.). Proceeding of a workshop on Lime in New Zealand Agriculture, Section V. Mechanisms of lime responses.

Holford, I.C.R. 1985. Effects of lime on yield and phosphate uptake by clover in raltion to changes in soil phosphate and related characteristics. Australian Journal of Soil Research 23, 75-83. 
Huang P.M., Violante A. 1986. Influence of organic acids on crystallization and surface properties of precipitation products of aluminum. In: Huang P.M., Schnitzer M. (Eds.). Interactions of soil minerals with natural organics and microbes. SSSA Spec. Publ. 17. Madison, WI: SSSA, pp. 159-221.

Jarrel, W.M., Page, A.L., Elseewi, A.A. 1980. Molybdenum in the environment. Residue Review 74, 1-43.

Jones, M.B., Ruckman, J.E., Williams, W.A., Koenigs, R.L. 1980. Sulfur diagnostic criteria as affected by age and defoliation of subclover. Agronomy Journal 72, 1043-1046.

Kabata-Pendias, A., PendiaS, H. 2000. Trace elements in soils and plants. Third Edition. CRC Press, Boca Raton, USA., 413 p.

Karla, Y. 1998. Handbook of reference methods for plant analysis. Soil and Plant Analysis Council, Inc. CRC Press., 320 p.

López, R., Alvear, M., Gianfreda, L. Mora, M. 2007. Molybdenum availability in Andisols and its effect on biological paramters of soil and red clover (Trifolium pratense L.). Soil Science 172 (11), 913-924.

Marschner, H. 1995. Mineral nutrition of higher plants. Acad. Press, London, UK.

Miltimore, J.E., Mason, J.L. 1971. Copper to molybdenum fatio and molybdenum and copper concentrations in ruminants feeds. Canadian Journal of Animal Science 51, 193-200.

Mitchell, R., Reith, J., Johnston, I. 1957. Trace element uptake in relation to soil content. Journal of the Science of Food and Agricultural 8: 85159.

Mora, M.L., Barrow, N.J. 1996. The effects of time of incubation on the relation between charge and $\mathrm{pH}$ of soil. European Journal of Soil Science 47, 131-136.

Mora, M.L., Baeza, G., Pizarro, C., Demanet, R. 1999. Effect of calcitic and dolomitic lime on physicochemical properties of a Chilean Andisol. Communication in Soil Science and Plant Analysis 30, 427-439.

Mora, M.L., Cartes, P., Demanet, R., Cornforth, I.S. 2002. Effects of lime and gypsum on pasture growth and composition on an aid andisol in chile, South America. Communication in Soil Science and Plant Analysis 33 (13\&14), 2069-2081.
Mora, M.L., Shene, C., Violante, A., Demanet, R., Bolan N.S. 2005. The effect of organic matter and soil chemical properties on sulfate availabity in Chilean volcanic soils. In: Huang, P.M., Violante, A., Bollang, J.M., Vityakon, P. (Eds.). Soil abiotic and biotic interactions and the impact on the ecosystem and human welfare, Science Publishers, USA, pp. 223 - 244.

Mora, M.L., Vistoso, E., Jara, A., Cartes, P., Demanet, R. 2006. Effect of phosphorus on molybdenum or boron uptake by forage species in Chilean Andisols. 3rd International Symposium "Phosphorus Dynamics in Soil-Plant Continuum". Uberlândia, Minas Gerais-Brasil, pp. 214-215.

Murphy, J., Riley, J.P. 1962. A modified single solution method for the determination of phosphate in natural waters. Analytica Chimica Acta 27, 31- 36.

Naidu, R., Syers, J.K., Tillman, J., Kirkman, J.H. 1990. Effect of liming and added phosphate on charge characteristic of acid soils. European Journal of Soil Science 41, 157-164.

O'Dell, B.L. 1997. The concept of trace element antagonism: The $\mathrm{Cu}-\mathrm{Mo}-\mathrm{S}$ triangle. Journal of Nutrition 127 (5 suppl.), 1045S-1047S.

Ortega, F., Galdames, R., Aguilera, A., Romero, O., Ruiz, I., Soto, P., Torres, A., Campos, H. 1998. Advances in red clover breeding in Chile. In: Grand, C . (Ed.). Fifteeth Trifolium Conference. Madison, Wisconsin, USA.

Parfitt, R.L. 1978. Anion adsorption by soils and soil materials. Advances in Agronomy 30, 1-50.

Sadzawka, A.M., Carrasco, M.A., Grez, R., Mora, M.L. 2004. Métodos de análisis recomendados para los suelos chilenos. Comisión de Normalización y Acreditación, Sociedad Chilena de la Ciencia del Suelo, Santiago, Chile. $113 \mathrm{p}$.

Sadzawka, A.M., Flores, H., Carrasco, M.A., Grez, R, Mora, M.L., Neaman, A., Demanet, R 2007. Métodos de análisis de lodos y de suelos. Comisión de Normalización y Acreditación, Sociedad Chilena de la Ciencia del Suelo. 105 p.

Sinclair, A.G., Morrison, J.D., Smith, L.C., Dodds, K.G. 1997. Determination of optimum nutrient element ratios in plant tissue. Journal of Plant Nutrition 20(9), 1069-1083. 
Soltanpour, P.N., Jones, J.P., Workman, S.M. 1982. Optical emission spectrometry. In: Page, A.L. (Ed.) Methods Soil Analysis. American Society of Agronomy, Madison, W.I., pp. 29-65.

Vistoso, E. 2005. Factores que influencian la dinámica del molibdeno en el sistema sueloplanta en Andisoles del Sur de Chile. Doctoral Thesis. Post-degree Program in Science of Natural Resources, Universidad de La Frontera, Temuco, Chile, pp. 9-31. www.ufro.cl/rrnn

Vistoso, E., Mora, M.L., Bolan, N. 2005. Phosphorus and molybdenum interactions in the Andisols of Chile. Proceeding Workshop Development in Fertilizer Application Technologies and Nutrient management FLRC, Massey University, $\mathrm{N}^{\circ} 18$.

Vistoso. E., Bolan, N., Theng, B., Mora, M. 2009. Kinetics of molybdate and phosphate sorption by some Chilean Andisols. Journal of Soil Science and Plant Nutrition 9 (1), 55-68.
Wheeler, D. 1998. Investigation into the mechanisms causing lime responses in a grass/clover pasture on a clay loam soil. New Zealand Journal Agricultural Research 41, 497515.

Whitehead, D.C. 2000. Nutrient elements in grassland. Soil-Plant-Animal Relationships. CABI Publishing. University Press, Cambridge, UK. 369 p.

Xie, R.J., MCKenzie, A.F. 1991. Molybdate sorption-desorption in soils treated with phosphate. Geoderma 48, 321-33.

Zhang, P.C., Sparks, D.L. 1989. Kinetics and mechanisms of molybdate adsorption/desorption at the goethite/water interface using pressurejump relaxation. Soil Science Society America Journal 53, 1028-1034. 